\title{
Evaluation of the Phytoremediation Potential of Two Medicinal Plants
}

(Penilaian Potensi Fitoremediasi bagi Dua Tumbuhan Ubatan)

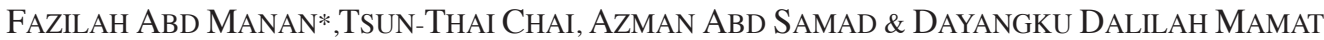

\begin{abstract}
Heavy metal pollution leads to human health problems and represents a constant threat to the environment. Pollutant clean-up using conventional methods are often hampered by high cost and ineffective pollutant removal. Phytoremediation technique is a preferable alternative due to its minimal side effects to the environment in addition to reasonable treatment cost. In this study, we investigated the potential of Centella asiatica and Orthosiphon stamineus as phytoremediation agents. Both species were grown in contaminated soil obtained from industrial land. Plant growth response and their ability to accumulate and translocate zinc, copper and lead were assessed. From this study, root growth of C. asiatica was compromised when grown in contaminated soil. Copper was highly accumulated in $\mathrm{C}$. asiatica roots while the leaves were more concentrated with zinc and lead. Conversely, all three tested metals were highly detected in the roots of $\mathrm{O}$. stamineus, although the root elongation was not adversely affected. Low amount of metals in the stems of both species permits longer stem length. Correlation study showed that the accumulation of zinc, copper and lead in plant tissues varies depending on plant species and the type of metals. Based on the bioaccumulation, translocation and enrichment factor, our study showed that C. asiatica was tolerant towards zinc, copper and lead; hence suitable for phytoextraction. By contrast, O. stamineus acted as a moderate accumulator of the tested metal elements.
\end{abstract}

Keywords: Centella asiatica; heavy metals; Orthosiphon stamineus; phytoremediation

\section{ABSTRAK}

Pencemaran logam berat membawa kepada masalah kesihatan manusia dan menjadi ancaman berterusan kepada alam sekitar. Pembersihan menggunakan kaedah konvensional sering terjejas oleh kos yang tinggi sedangkan penyingkiran pencemar tidak efektif. Sebagai alternatif, teknik fitoremediasi menjadi pilihan utama disebabkan oleh kesan sampingan minimum terhadap alam sekitar dengan kos rawatan yang munasabah. Dalam kajian ini, kami mengkaji potensi Centella asiatica dan Orthosiphon stamineus sebagai agen fitoremediasi. Kedua-dua spesies ditumbuhkan menggunakan tanah tercemar dari kawasan perindustrian. Tindak balas pertumbuhan, kebolehan mengumpul dan mentranslokasi zink, kuprum dan plumbum dinilai. Daripada kajian ini, pertumbuhan akar C. asiatica dikompromi apabila tumbuh pada tanah tercemar. Kuprum terkumpul pada akar C. asiatica manakala daunnya mengandungi lebih banyak zink dan plumbum. Sebaliknya, semua logam yang dikaji dikesan dengan sangat tinggi di dalam akar O. stamineus, walaupun pertumbuhan akar tidak terjejas. Jumlah logam yang rendah pada batang kedua-dua spesies membolehkan ia tumbuh lebih panjang. Analisis korelasi menunjukkan pengumpulan zink, kuprum dan plumbum dalam tisu tumbuhan adalah berbeza mengikut spesies dan jenis logam. Berdasarkan faktor bio-akumulasi, faktor translokasi dan faktor pengkayaan, kajian kami menunjukkan bahawa C. asiatica adalah toleran terhadap zink, kuprum dan plumbum, maka ia sesuai untuk fito-ekstraksi. Walau bagaimanapun, O. stamineus bertindak sebagai pengumpul sederhana bagi logam yang dikaji.

Kata kunci: Centella asiatica; fitoremediasi; logam berat; Orthosiphon stamineus

\section{INTRODUCTION}

Heavy metals such as zinc $(\mathrm{Zn})$, copper $(\mathrm{Cu})$ and lead $(\mathrm{Pb})$ are ubiquitous in the environment due to natural and anthropogenic activities. Rapid development in industrial sectors has led to the productions of heavy metals that contaminate the surroundings and significantly accumulated in certain organisms (Yap et al. 2004). Although $\mathrm{Zn}$ and $\mathrm{Cu}$ are important micronutrients, both are highly toxic to cells when present at excessive levels (Singh et al. 2011). Pb, on the other hand has no specific biological function and is known to have harmful effects on living organisms (Sengar et al.2008). The presence of heavy metals in industrial lands, especially those located adjacent to residential areas, necessitates prompt cleanup action. However, current conventional techniques, such as the dig-and-dump approach, are expensive and may further contaminate more sites (Van Ginneken et al. 2008).

Phytoremediation, an inexpensive pollutant clean-up method using plants, has become a feasible alternative. In phytoremediation, plants may adopt strategies such as phytostabilisation, phytoextraction, phytovolatilisation, 
phytofiltration, phytodegradation, rhizodegradation and/ or phytodesalination (Ali et al. 2013). The functions of plants as accumulators, excluders or indicators have been suggested based on their ability to grow on metal contaminated soils (Baker \& Walker 1990). Accumulators take up heavy metals and translocate them into above ground tissues, while excluders avoid excessive transport of metal ions from root to shoot (Zarinkamar et al. 2013). Indicator species are plants that can tolerate existing level of metals and actively accumulate metals in their above-ground parts. Such tolerance is achieved by the production of intracellular metal-binding compounds or by the compartmentalisation of metals in non-responsive plant parts (Ghosh \& Singh 2005).

Plant physiological and biochemical features are normally altered in response to metal stress. Previous studies reported that plants suffering from $\mathrm{Zn}$ toxicity experienced limits in root and shoot growth (Malik et al. 2011) similar to plants exposed to Pb (Sharma \& Dubey 2005) and $\mathrm{Cu}$ (Fernandes \& Henriques 1991). Biochemical processes such as respiration and photosynthesis are also compromised due to interference from these metal elements (Keunen et al. 2011). To date, many reviews are available on various aspects of plant responses towards heavy metal stress (Ghosh \& Singh 2005; Nagajyoti et al. 2010; Van Der Ent et al. 2013).

Nowadays, the role of medicinal plant is not only limited as the source of traditional medicine. The economic value of these plants has been improved due to increasing demand of plant-based products in industries such as foods, pharmaceuticals, cosmetics and even ornaments. In addition, as plants also respond to changing environmental conditions, the biotechnology approach has open more space for medicinal plants to be used as an agent for bioremediation. Two plant species, Centella asiatica and Orthosiphon stamineus were investigated on their potential to be used as phytoremediation agents.

C. asiatica is from Umbelliferare family and contain high level of antioxidants (Hamid et al. 2002). The extract helps to cure many skin related problems besides useful for wound healing (Gohil et al. 2010; Rosalizan et al. 2008). The other species used in this study, O. stamineus is a plant from family Lamiaceae. O. stamineus also rich in antioxidants (Ahamed \& Abdul 2010) and commonly used to treat gout, high blood pressure, hepatitis, jaundice and many other diseases (Ameer et al. 2012).

Previous studies have shown that $C$. asiatica and $O$. stamineus have the ability to chelate or take up metals (Abdu et al. 2011; Mohd Salim et al. 2013). However, current understanding of the metal tolerance/resistance of these plants and their strategy to accumulate heavy metals from contaminated soil is still limited. Hence, in this study, we had three main objectives. First, to characterise the physical changes of plants grown in contaminated soil. Second, to determine the heavy metals content in plant tissues and third, to assess the phytoremediation strategies of the plants.

\section{MATERIALS AND METHODS}

\section{SOIL SAMPLES}

Metal-contaminated soil samples were collected from the roadside in the Pasir Gudang Industrial Park, Johor, Malaysia in February, 2013. The sampling location was about $20 \mathrm{~m}$ from factories that produce heavy metal wastes. Soil samples (top $20 \mathrm{~cm}$ layer) were placed into a large ziplock bag and brought to the laboratory for analysis. Soil samples were cleaned by removal of dead leaves, debris and insects. Samples were stored at room temperature prior to plant growth study.

\section{PLANT GROWTH CONDITIONS}

$C$. asiatica were planted from rhizomes while $O$. stamineus were grown from stem cuttings in pots containing metalcontaminated soil. Control plants were grown in noncontaminated soil purchased from a local nursery. Plants were grown outdoor under shady conditions and watered twice daily with tap water. After three months, the plants were harvested. The length of the longest primary root and stem were measured. The $\mathrm{Zn}, \mathrm{Cu}$ and $\mathrm{Pb}$ content of the root, stem and leaf tissues of both test species were also measured.

\section{DETERMINATION OF HEAVY METAL CONTENT}

Plant samples were cleaned and separated into roots, leaves and stems. Prior to heavy metal analysis, both plant and soil samples were dried in the oven at $80^{\circ} \mathrm{C}$ for $48 \mathrm{~h}$. Dried samples were pulverized into powder and approximately $0.5 \mathrm{~g}$ samples were subjected to acid digestion process. Nitric acids followed by perchloric acid (2:1) were added to powdered plant samples. Soil samples were treated similarly. Digested samples were further diluted and aliquots were used for estimation of metal ( $\mathrm{Zn}$, $\mathrm{Cu}$ and $\mathrm{Pb}$ ) concentrations. The measurements of these metal elements were conducted using Atomic Absorption Spectrophotometer Model AAnalyst 400.

\section{HEAVY METAL ANALYSIS}

The accumulation and translocation of $\mathrm{Zn}, \mathrm{Cu}$ and $\mathrm{Pb}$ in $O$. stamineus and $C$. asiatiaca were measured using bioconcentration factor $(\mathrm{BCF})$, translocation factor $(\mathrm{TF})$ and enrichment factor (EF) as:

$\mathrm{BCF}$ is the metal concentration in roots/ metal concentration in soil; TF is the metal concentration in leaves/ metal concentration in roots; and $\mathrm{EF}$ is the metal concentration in leaves/ metal concentration in soil.

\section{DATA ANALYSIS}

Experiments were carried out in triplicates. Data were analysed using Microsoft Excel 2007 and reported as mean \pm standard errors. Correlation coefficients analyses were performed using Pearson's coefficient in Microsoft 
Excel 2007 and reported at the significance level of $p<0.05$.

\section{RESULTS AND DISCUSSION}

$\mathrm{Zn}, \mathrm{Cu}$ and $\mathrm{Pb}$ contents in soil samples Higher $\mathrm{Zn}, \mathrm{Cu}$ and $\mathrm{Pb}$ contents were detected in soil collected from industrial land with the descending order of $\mathrm{Cu}>\mathrm{Zn}>\mathrm{Pb}$ (Table 1). Although the concentrations of these metals are acceptable and do not require urgent clean-up according to US EPA (2002), these amounts might still contribute to human health risks (NYS DEC 2006). The $\mathrm{Zn}$ and $\mathrm{Cu}$ contents of the contaminated soil were 54.6-fold and 1963.8-fold higher, respectively, compared with the non-contaminated control soil. $\mathrm{Pb}$ was detected in the contaminated soil but undetectable in the control soil.

\section{THE PHYSICAL PROPERTIES OF PLANTS IN CONTAMINATED AND NON-CONTAMINATED SOILS}

$C$. asiatica and $O$. stamineus grown on contaminated soil appeared healthy and did not show any visual differences from the control plants grown in control soil. However, we found that root and stem growth of the plants to be variably affected by the treatment with contaminated soil (Figure 1). C. asiatica grown in contaminated soil had significantly reduced root elongation compared with control plants. Since roots are in direct contact with soil, retardation of root growth is one of the implications of metal stress (Gwozdz et al. 1997). By contrast, root length of $O$. stamineus grown in contaminated soil was $30 \%$ longer compared with control. This suggests that root elongation of $O$. stamineus was not adversely affected by the contaminated soil treatment. Such a discrepancy between the two test species may reflect a species-specific adaptation towards heavy metal stress. For some hyperaccumulator species, the root elongation was positively observed when plants were exposed to excess $\mathrm{Zn}$ and $\mathrm{Cu}$ (Whiting et al. 2000).

\section{HEAVY METAL ACCUMULATION IN PLANT TISSUES}

$C$. asiatica and $O$. stamineus accumulated significant amounts of $\mathrm{Zn}, \mathrm{Cu}$ and $\mathrm{Pb}$ in their tissues. In C. asiatica, the highest amount of $\mathrm{Zn}$ and $\mathrm{Pb}$ were detected in the leaves, followed by the roots and stems. Accumulation of $\mathrm{Zn}$ in the leaves might be due to its importance in biochemical reactions especially in photosynthesis (Mohd et al. 2013). High $\mathrm{Pb}$ content in the leaves indicates active translocations of $\mathrm{Pb}$ from roots to leaves. In contrast to $\mathrm{Zn}$ and $\mathrm{Pb}, \mathrm{Cu}$ accumulation was higher in $C$. asiatica root system compared to leaves and stems (Figure 2). This indicates that $\mathrm{Cu}$ was not preferably or was only slowly translocated to the aboveground tissues in $C$.asiatica.

For $O$. stamineus, all metals were detected at the highest concentrations in plant roots, followed by the leaves and at the lowest amount in stems (Figure 3). Lower metal contents in the stems might explain the unaffected stem elongation in both species (Figure 1). When grown in contaminated soil, the stem of $C$. asiatica plants was $33.3 \%$ longer, while O. stamineus showed no significant changes in stem length. The lower capacities of $O$. stamineus for $\mathrm{Pb}$ translocation to the stem, in comparison to $C$. asiatica, may be due to differences in their stem morphology. $\mathrm{Pb}$ translocation to different plant organs varies by species (Antosiewicz 1992). The phenomena of high accumulation of metals in the roots apparently occur as roots will also permit metal ions to pass through their system when taking up water and nutrients (Clemens et al. 2002). From the roots, dissolved

TABLE 1. Heavy metal contents of contaminated soil and non-contaminated control soil

\begin{tabular}{lccc}
\hline & & Content $(\mu \mathrm{g} / \mathrm{g})$ & \\
& $\mathrm{Zn}$ & $\mathrm{Cu}$ & $\mathrm{Pb}$ \\
\hline Contaminated soil & $10320.33 \pm 76.15$ & $18130.33 \pm 139.37$ & $268.80 \pm 0.95$ \\
Control soil & $189.00 \pm 0.96$ & $9.23 \pm 0.09$ & $\mathrm{~N} / \mathrm{A}$ \\
\hline
\end{tabular}

Data are mean \pm standard errors $(n=3)$
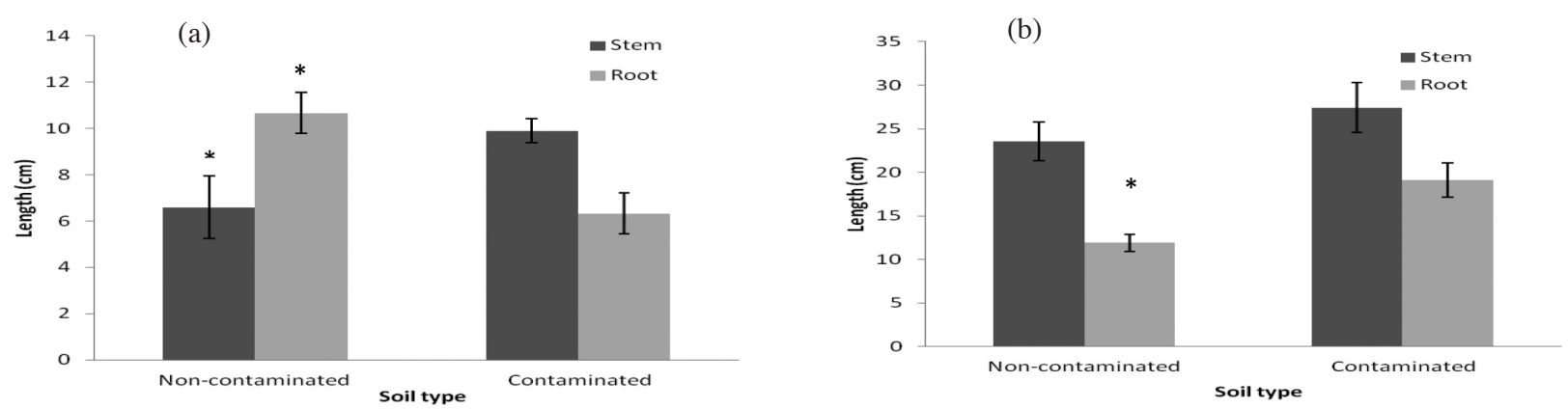

FIGURE 1. Stem and root length of Centella asiatica (a) and Orthosiphon stamineus (b) plants grown in noncontaminated control soil and contaminated soil. Data are means \pm standard errors $(n=3)$.

Significant differences $(*)$ were determined by a t-test $(p<0.05)$ 
metal ions will be translocated to other parts of the plant (Punz \& Sieghardt 1993).

Since both species analysed in this study were medicinal plants and the accumulation of $\mathrm{Zn}, \mathrm{Cu}$ and $\mathrm{Pb}$ were above the limit of Malaysian Food Regulations (1985), there is risk of unsafe human consumption. According to the guideline, the permitted level for $\mathrm{Zn}$ in food is 100 $\mathrm{mg} / \mathrm{g}, \mathrm{Cu} 30 \mathrm{mg} / \mathrm{g}$ and $\mathrm{Pb} 2 \mathrm{mg} / \mathrm{g}$ (Malaysia Food Act 1983 and Food Regulations 1985). Hence, species growing wildly at contaminated land might be more suitable for phytoremediation rather than human utilisation.

\section{ACCUMULATION AND TRANSLOCATION OF METALS}

The capacity of both species to accumulate and transport metals was characterised by determining their bioconcentration factor $(\mathrm{BCF})$, translocation factor $(\mathrm{TF})$ and enrichment factor (EF) (Table 2). Although C. asiatica and $O$. stamineus took up significant amount of $\mathrm{Zn}, \mathrm{Cu}$ and $\mathrm{Pb}$, none of them are hyperaccumulator due to $\mathrm{EF}$ value of less than 1 (Lorestani et al. 2011). Both species are also unsuitable as phytostabilisation agents, which normally requires them to have $\mathrm{BCF}$ value of greater than 1 and $\mathrm{TF}$ value of less than 1 (Yoon et al. 2006).
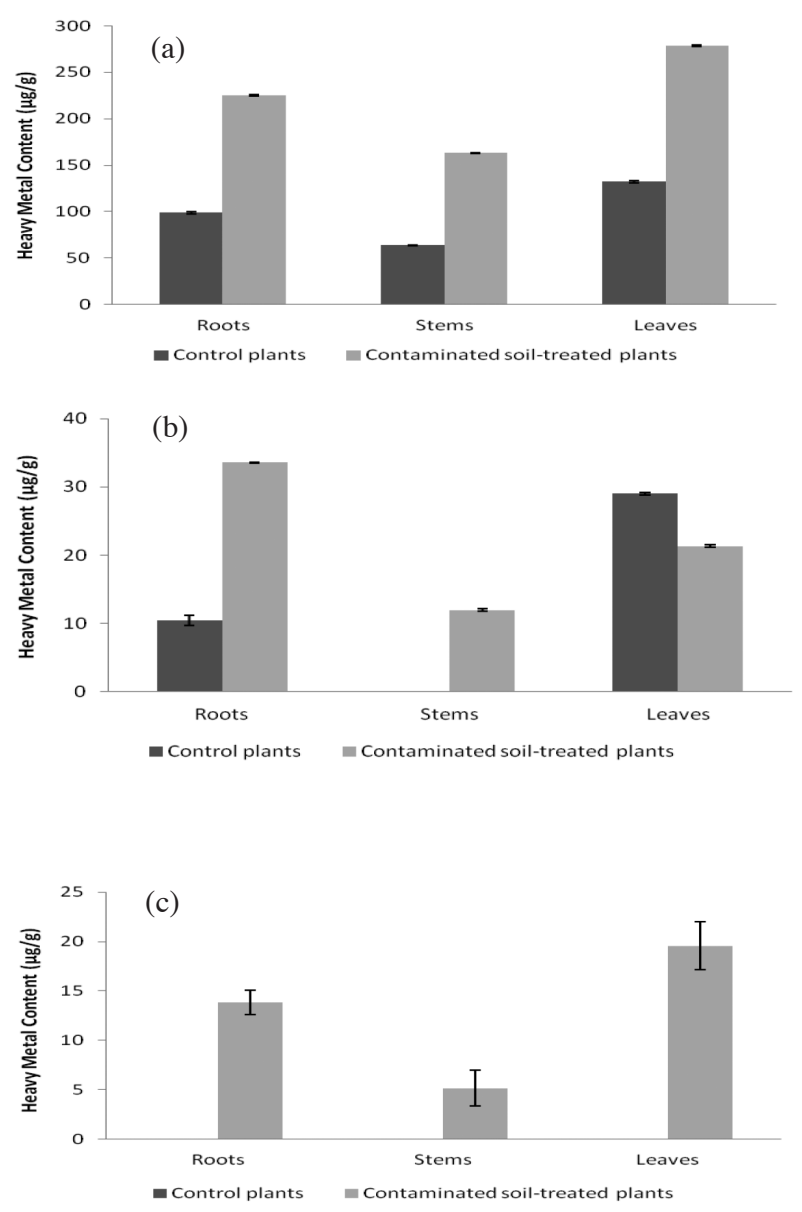

FIGURE 2. Contents of $\mathrm{Zn}(\mathrm{a}), \mathrm{Cu}$ (b) and $\mathrm{Pb}$ (c) in plants tissues of Centella asiatica grown in control soil and in contaminated soil. Data are means \pm standard errors $(n=3)$
C. asiatica had BCF value smaller than 1 and TF greater than 1 . This implies that although $C$. asiatica is neither a hyperaccumulator nor a potential phytostabilisation agent, this species is tolerant to $\mathrm{Zn}, \mathrm{Cu}$ and $\mathrm{Pb}$. The $\mathrm{BCF}$ values for $\mathrm{Zn}$ and $\mathrm{Pb}$ which fell between 0.01 to 0.10 indicate $C$. asiatica as a low accumulator for these metals. BCF value of less than 0.01 signifies $C$. asiatica as a non-accumulator for $\mathrm{Cu}$. BCF values of less than 0.2 are normal for plants growing in polluted soil (Yoon et al. 2006). TF value of greater than 1 indicates that $C$. asiatica is suitable for phytoextraction due to its capacity to translocate metals from root to shoot. On the other hand, O. stamineus is inappropriate for phytoextraction as it exhibited low TF and BCF values. The BCF value between 0.1 and 1 shows that $O$. stamineus is a moderate accumulator species. TF value of less than 1 is a sign that more metals are stored in the roots of $O$. stamineus than the aboveground tissues.

\section{CORRELATION PROFILES OF METAL ACCUMULATIONS}

Correlation coefficient for accumulation of $\mathrm{Zn}, \mathrm{Cu}$ and $\mathrm{Pb}$ in different plant tissues are presented in Table 3. A strong correlation of $\mathrm{Zn}$ accumulation in leaves and roots of $C$. asiatica were observed $(r=0.9811)$, while for $\mathrm{Cu}$, it was
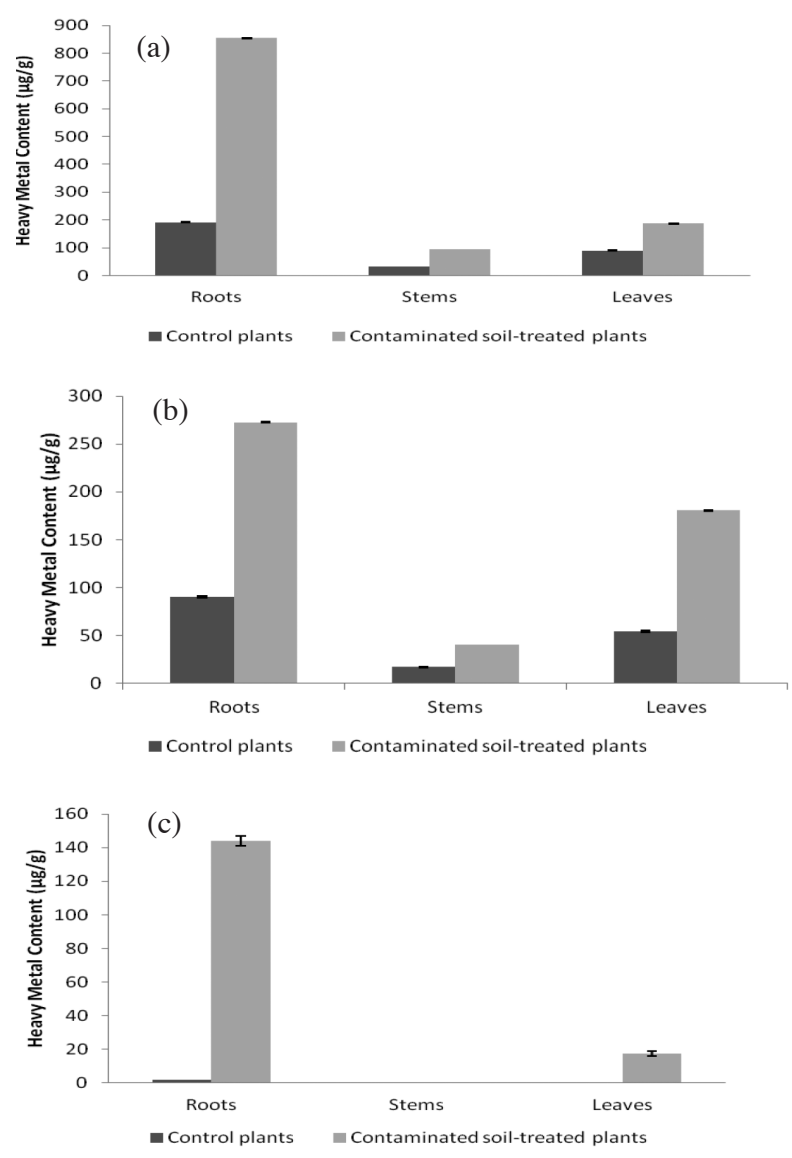

FIGURE 3. Contents of $\mathrm{Zn}(\mathrm{a}), \mathrm{Cu}$ (b) and $\mathrm{Pb}$ (c) in plants tissues of Orthosiphon stamineus grown in control soil and in contaminated soil. Data are means \pm standard errors $(n=3)$ 
TABLE 2. Capacity for accumulation and translocation of $\mathrm{Zn}, \mathrm{Cu}$ and $\mathrm{Pb}$ in Orthosiphon stamineus and Centella asiatica

\begin{tabular}{llccccc}
\hline & \multicolumn{3}{c}{ Centella asiatica } & \multicolumn{3}{c}{ Orthosiphon stamineus } \\
& $\mathrm{BCF}$ & $\mathrm{TF}$ & $\mathrm{EF}$ & $\mathrm{BCF}$ & $\mathrm{TF}$ & $\mathrm{EF}$ \\
\hline $\mathrm{Zn}$ & 0.02 & $\mathbf{1 . 3 4}$ & 0.03 & 0.08 & 0.47 & 0.02 \\
$\mathrm{Cu}$ & 0.002 & $\mathbf{2 . 7 7}$ & 0.001 & 0.02 & 0.60 & 0.01 \\
$\mathrm{~Pb}$ & 0.05 & $\mathbf{1 . 4 2}$ & 0.07 & 0.54 & 0.12 & 0.06 \\
\hline
\end{tabular}

$\mathrm{BCF}$, bioconcentration factor; $\mathrm{TF}$, translocation factor; $\mathrm{EF}$, enrichment factor. Values $>1$ are in bold

highly accumulated in the leaves and stems of the plant ( $r=0.9598$ ). For O. stamineus, roots were more significant in accumulating $\mathrm{Zn}, \mathrm{Cu}$ and $\mathrm{Pb}$. $\mathrm{Zn}$ accumulation was highly correlated in the roots and stems, while $\mathrm{Cu}$ and $\mathrm{Pb}$ in the roots were highly correlated with the leaves. The variation of correlations might be due to natural controlling mechanisms of species to absorb certain quantity of specific metals from surroundings into their tissues.

Since the uptake of certain metals is regularly affected by the presence of other metal elements, correlation coefficients between the metal accumulated in different tissues were determined (Table 4). Significant positive correlations were observed between $\mathrm{Zn}$ and $\mathrm{Cu}$ accumulation in $C$. asiatica leaves with $r=0.8436$. Similarly, $\mathrm{Zn}$ and $\mathrm{Cu}$ also positively correlated in the leaves and stems of Orthosiphon stamineus ( $r=0.9918$ and 0.8094 , respectively). This demonstrates the possible occurrence of synergistic uptake of $\mathrm{Zn}$ and $\mathrm{Cu}$. Conversely, $\mathrm{Pb}$ might perturb the uptake of $\mathrm{Zn}$ and $\mathrm{Cu}$ into plant tissues. This is because $\mathrm{Pb}$ and $\mathrm{Zn}$ were just highly correlated in the roots of $O$. stamineus, while $\mathrm{Pb}$ and $\mathrm{Cu}$ were not highly correlated in any of the plant tissues.

The ability of $C$. asiatica to survive in metal contaminated soil suggests their potential in phytoremediation. Our findings agreed with previous report of the capability of this species in removing $\mathrm{Cu}$ from wastewater (Mokhtar et al. 2011). A work by Tripathi et al. (2012) also reported high TF value for $C$. asiatica in translocating arsenic. In this study, the competence of O. stamineus to take up metals from soil and moderately accumulate metals has been demonstrated.

The result from this study is important to select plants that have the capacity to be used as phytoremediation agent. In future, detail physiological and biochemical characteristics of both plants could be conducted to understand the mechanisms occur when plants are exposed to heavy metals stress. This may include the determination of plant biomass, as well as the detection of important plant biomolecules such as chlorophyll. For a long term planning, species potentially used for phytoremediation can be planted at contaminated area, taking advantage of their fast growing capacity to accelerate soil clean-up process.

\section{CONCLUSION}

In this study, we have demonstrated that $C$. asiatica and $O$. stamineus had different strategies of removing heavy metals from soil. The roots of $O$. stamineus accumulated high concentrations of $\mathrm{Zn}, \mathrm{Cu}$ and $\mathrm{Pb}$, while the leaves of $C$. asiatica were more concentrated with $\mathrm{Zn}$ and $\mathrm{Pb}$. The stems of both test species accumulated metals not as much as other parts of the plants, thus did not affect

TABLE 3. Pearson correlation coefficient of metal contents in different plant tissues

\begin{tabular}{lcccccc}
\hline $\begin{array}{l}\text { Correlation between } \\
\text { tissues }\end{array}$ & \multicolumn{3}{c}{ Centella asiatica } & \multicolumn{3}{c}{ Orthosiphon stamineus } \\
& $\mathrm{Zn}$ & $\mathrm{Cu}$ & $\mathrm{Pb}$ & $\mathrm{Zn}$ & $\mathrm{Cu}$ & $\mathrm{Pb}$ \\
\hline Root-Stem & $0.1023^{*}$ & $-0.9286^{*}$ & $0.1877^{*}$ & $0.8231^{*}$ & $-0.8002^{*}$ & - \\
Root-Leaves & $0.9811^{*}$ & $-0.7871^{*}$ & 0.9123 & $-0.020^{*}$ & $0.7279^{*}$ & $0.8966^{*}$ \\
Stem-Leaves & $-0.0922^{*}$ & $0.9598^{*}$ & $-0.2310^{*}$ & $0.5513^{*}$ & $-0.1712^{*}$ & - \\
\hline
\end{tabular}

*Values are statistically significant at $p<0.05$

TABLE 4. Pearson correlation coefficient of metal contents in respective plant tissues

\begin{tabular}{|c|c|c|c|c|c|c|}
\hline \multirow{2}{*}{$\begin{array}{l}\text { Correlation between } \\
\text { metals }\end{array}$} & \multicolumn{3}{|c|}{ Centella asiatica } & \multicolumn{3}{|c|}{ Orthosiphon stamineus } \\
\hline & Roots & Leaves & Stems & Roots & Leaves & Stems \\
\hline $\mathrm{Zn}-\mathrm{Cu}$ & $-0.9575^{*}$ & $0.8436^{*}$ & $0.1888^{*}$ & $-0.7857 *$ & $0.9918 *$ & $0.8094 *$ \\
\hline $\mathrm{Zn}-\mathrm{Pb}$ & $-0.4601 *$ & $-0.2484 *$ & $-0.3818 *$ & $0.9998 *$ & $0.4437 *$ & - \\
\hline $\mathrm{Cu}-\mathrm{Pb}$ & $0.6967 *$ & 0.3107 & -0.9797 & $-0.7726^{*}$ & $0.3254 *$ & - \\
\hline
\end{tabular}

*Values are statistically significant at $p<0.05$ 
the stem elongation. The root of $O$. stamineus was more adaptive in contaminated soil as the elongation was not affected with high metal concentrations. From this study, the accumulation of $\mathrm{Zn}, \mathrm{Cu}$ and $\mathrm{Pb}$ in plant tissues varies based on plant species and metal elements. The BCF, TF and EF values indicated the capacity of $C$. asiatica to extract metals and $O$. stamineus as a moderate accumulator of $\mathrm{Zn}$, $\mathrm{Cu}$ and $\mathrm{Pb}$. This indicates the potential of these species to be further developed as phytoremediation agent.

\section{ACKNOWLEDGEMENTS}

The authors would like to thank Universiti Teknologi Malaysia, Johor Bahru, Malaysia for the research grant (Potential Academic Staff: Vote number: Q.J130000.2735.00K13).

\section{REFERENCES}

Abdu, A., Aderis, N., Abdul-Hamid, H., Majid, N.M., Jusop, S., Karam, D.S. \& Ahmad, K. 2011. Using Orthosiphon stamineus $B$. for phytoremediation of heavy metals in soils amended with sewage sludge. American Journal of Applied Sciences 8(4): 323-331.

Ahamed, B.M. \& Abdul, M.A. 2010. Medicinal potentials of Orthosiphon stamineus benth. WebmedCentral CANCER 1(12): 1-7.

Ali, H., Khan, E. \& Sajad, M.A. 2013. Phytoremediation of heavy metals-concepts and applications. Chemosphere 91(7): 869-881.

Ameer, O.Z., Salmani, M., Asmawi, M.Z., Ibraheem, Z.O. \& Yam, M.F. 2012. Orthosiphon stamineus: Traditional uses, phytochemistry, pharmacology, and toxicology. Journal of Medicinal Food 15(8): 678-690.

Antosiewicz, D.M. 1992. Adaptation of plants to an environment polluted with heavy metals. Acta Societatis Botanicorum Poloniae 61(2): 281-299.

Baker, A.J.M. \& Walker, P.L. 1990. Ecophysiology of metal uptake by tolerant plants. In Heavy Metal Tolerance in Plants: Evolutionary Aspects, edited by Shaw, A.J. Boca Raton: CRC Press. pp. 155-177.

Clemens, S., Palmgren, M.G. \& Krämer, U. 2002. A long way ahead: Understanding and engineering plant metal accumulation. Trends in Plant Science 7(7): 309-315.

Fernandes, J. \& Henriques, F. 1991. Biochemical, physiological, and structural effects of excess copper in plants. The Botanical Review 57(3): 246-273.

Ghosh, M. \& Singh, S. 2005. A review on phytoremediation of heavy metals and utilization of it's by products. Applied Ecology and Environmental Research 3(1): 1-18.

Gohil,K., Patel,J.\& Gajjar, A. 2010. Pharmacological review on Centella asiatica: A potential herbal cure-all. Indian Journal of Pharmaceutical Sciences 72(5): 546-556.

Gwóźdź, E.A., Przymusiński, R., Rucińska, R. \& Deckert, J. 1997. Plant cell responses to heavy metals: Molecular and physiological aspects. Acta Physiologiae Plantarum 19(4): 459-465.

Hamid, A.A., Shah, Z.M., Muse, R. \& Mohamed, S. 2002. Characterisation of antioxidative activities of various extracts of Centella asiatica (L) Urban. Food Chemistry 77(4): 465-469.
Keunen, E., Remans, T., Bohler, S., Vangronsveld, J. \& Cuypers, A. 2011. Metal-induced oxidative stress and plant mitochondria. International Journal of Molecular Sciences 12(10): 6894-6918.

Lorestani, B., Cheraghi, M. \& Yousefi, N. 2011. Phytoremediation potential of native plants growing on a heavy metals contaminated soil of copper mine in Iran. World Acad. Sci. Eng. Techno. 77: 377-382.

Malaysia Food Act 1983 and Food Regulations 1985: Details on Food Regulations amendments from 1987 to January, 1994 : All amendments up to January, 1994. 1994. Kuala Lumpur: MDC Sdn. Bhd.

Malik, N., Chamon, A., Mondol, M., Elahi, S. \& Faiz, S. 2011. Effects of different levels of zinc on growth and yield of red amaranth (Amaranthus sp.) and rice (Oryza sativa, VarietyBR49). Journal of the Bangladesh Association of Young Researchers 1(1): 79-91.

Mohd, S.N., Majid, N.M., Shazili, N.A.M. \& Abdu, A. 2013. Assessment of Melaleuca cajuputi as heavy metals phytoremediator for sewage sludge contaminated soil. American Journal of Applied Sciences 10(9): 1087-1092.

Mohd Salim, R.J., Adenan, M.I., Amid, A., Jauri, M.H. \& Sued, A.S. 2013. Statistical analysis of metal chelating activity of Centella asiatica and Erythroxylum cuneatum using response surface methodology. Biotechnology Research International 2013: Article ID 137851.

Mokhtar, H., Morad, N. \& Fizri, F.F.A. 2011. Phytoaccumulation of copper from aqueous solutions using Eichhornia crassipes and Centella asiatica.Int.J. Environ. Sci.Dev. 2(3): 205-210.

Nagajyoti, P., Lee, K. \& Sreekanth, T. 2010. Heavy metals, occurrence and toxicity for plants: A review. Environmental Chemistry Letters 8(3): 199-216.

NYS DEC. 2006. New York State Brownfield cleanup program development of soil cleanup objectives technical support document. New York State Department of Environmental Conservation and New York State Department of Health, Albany, NY. http://www.dec.ny.gov/chemical/34189.html. Accessed on 25 January 2014.

Punz, W.F. \& Sieghardt, H. 1993. The response of roots of herbaceous plant species to heavy metals. Environmental and Experimental Botany 33(1): 85-98.

Rosalizan, M., Rohani, M., Khatijah, I. \& Shukri, M. 2008. Physical characteristics, nutrient contents and triterpene compounds of ratoon crops of Centella asiatica at three different stages of maturity. Journal of Tropical Agriculture and Food Science 36(1): 43-51.

Sengar, R.S., Gautam, M., Sengar, R.S., Garg, S.K., Sengar, K. \& Chaudhary, R. 2008. Lead stress effects on physiobiochemical activities of higher plants. Reviews of Environmental Contamination and Toxicology 196: 73-93.

Sharma, P. \& Dubey, R.S. 2005. Lead toxicity in plants. Brazilian Journal of Plant Physiology 17(1): 35-52.

Singh, R., Gautam, N., Mishra, A. \& Gupta, R. 2011. Heavy metals and living systems: An overview. Indian Journal of Pharmacology 43(3): 246-253.

Tripathi, P., Dwivedi, S., Mishra, A., Kumar, A., Dave, R., Srivastava, S., Shukla, M.K., Srivastava, P.K., Chakrabarty, D. \& Trivedi, P.K. 2012. Arsenic accumulation in native plants of West Bengal, India: Prospects for phytoremediation but concerns with the use of medicinal plants. Environmental Monitoring and Assessment 184(5): 2617-2631. 
US EPA. 2002. Supplemental guidance for developing soil screening levels for superfund sites. Washington, D.C.: Office of Solid Waste and Emergency Response. http://www.epa. gov/superfund/health/conmedia/soil/index.htm. Accessed on 25 January 2014.

Van Der Ent, A., Baker,A.J., Reeves, R.D., Pollard,A.J. \& Schat, H. 2013. Hyperaccumulators of metal and metalloid trace elements: Facts and fiction. Plant and Soil 362(1-2): 319-334.

Van Ginneken, L., Meers, E., Guisson, R., Ruttens, A., Elst, K., Tack, F.M., Vangronsveld, J., Diels, L. \& Dejonghe, W. 2007. Phytoremediation for heavy metal-contaminated soils combined with bioenergy production. Journal of Environmental Engineering and Landscape Management 15(4): 227-236.

Whiting, S.N., Leake, J.R., McGrath, S.P. \& Baker, A.J. 2000. Positive responses to $\mathrm{Zn}$ and $\mathrm{Cd}$ by roots of the $\mathrm{Zn}$ and $\mathrm{Cd}$ hyperaccumulator Thlaspi caerulescens. New Phytologist 145(2): 199-210.

Yap, C.K., Ismail, A. \& Tan, S.G. 2004. The impact of anthropogenic activities on heavy metal $(\mathrm{Cd}, \mathrm{Cu}, \mathrm{Pb}$ and $\mathrm{Zn})$ pollution: Comparison of the metal levels in the greenlipped mussel Perna viridis (Linnaeus) and in the sediment from a high activity site at Kg. Pasir Puteh and relatively low activity site at Pasir Panjang. Pertanika Journal of Tropical Agricultural Science 27(1): 73-78.

Yoon, J., Cao, X., Zhou, Q. \& Ma, L.Q. 2006. Accumulation of $\mathrm{Pb}, \mathrm{Cu}$, and $\mathrm{Zn}$ in native plants growing on a contaminated Florida site. Science of the Total Environment 368(2): 456464.

Zarinkamar, F., Saderi, Z. \& Soleimanpour, S. 2013. Excluder strategies in response to $\mathrm{Pb}$ toxicity in Matricaria chamomilla. Advances in Bioresearch 4(3): 39-49.
Fazilah Abd Manan*

Department of Biosciences and Health Sciences

Faculty of Biosciences and Medical Engineering

Universiti Teknologi Malaysia

81310 Johor Bahru, Johor Darul Takzim

Malaysia

Tsun-Thai Chai

Department of Chemical Science, Faculty of Science

Universiti Tunku Abdul Rahman

31900 Kampar, Perak Darul Ridzuan

Malaysia

Azman Abd Samad

Department of Biotechnology and Medical Engineering Faculty of Biosciences and Medical Engineering

Universiti Teknologi Malaysia

81310 Johor Bahru, Johor Darul Takzim

Malaysia

Dayangku Dalilah Mamat

Faculty of Biosciences and Medical Engineering

Universiti Teknologi Malaysia

81310 Johor Bahru, Johor Darul Takzim

Malaysia

*Corresponding author; email: fazilah@fbb.utm.my

Received: 25 June 2014

Accepted: 7 November 2014 